\title{
Car ownership motivations among undergraduate students in China, Indonesia, Japan, Lebanon, Netherlands, Taiwan, and USA
}

\section{AUTHOR(S):}

Belgiawan, Prawira Fajarindra; Schmöcker, Jan-Dirk; AbouZeid, Maya; Walker, Joan; Lee, Tzu-Chang; Ettema, Dick F.; Fujii, Satoshi

\section{CITATION:}

Belgiawan, Prawira Fajarindra ... [et al]. Car ownership motivations among undergraduate students in China, Indonesia, Japan, Lebanon, Netherlands, Taiwan, and USA.

Transportation 2014, 41(6): 1227-1244

\section{ISSUE DATE:}

2014-09-14

URL:

http://hdl.handle.net/2433/200709

\section{RIGHT:}

The final publication is available at Springer via http://dx.doi.org/10.1007/s11116-0149548-Z.; この論文は出版社版でありません。引用の際には出版社版をご確認ご利用くだ さい。; This is not the published version. Please cite only the published version. 


\title{
Car Ownership Motivations among
}

\section{Undergraduate Students in China, Indonesia,} Japan, Lebanon, Netherlands, Taiwan, and

\section{U.S.A.}

\author{
Prawira Fajarindra Belgiawan • Jan-Dirk Schmöcker • Maya Abou-Zeid • Joan \\ Walker • Tzu-Chang Lee • Dick F. Ettema • Satoshi Fujii
}

\begin{abstract}
Peak car" and related discussions suggest that especially younger people (age cohort until 30) have less desire to drive and purchase cars. This might though only be true for a limited range of developed countries. This study aims to understand the role of personal background and the country context influencing future car ownership decisions of younger people in seven countries (China, Indonesia, Japan, Lebanon, Netherlands, Taiwan, and United States of America). The main foci of this research are undergraduate students where it is expected that their current attitudes and habits will influence their travel behavior after they graduate and obtain a job. A web survey asked students about their attitudes towards car and public transportation, social norms, their socio-demographic situations, current mobility patterns and the intention to own a car after graduation. We conducted a descriptive analysis as well as correlation analysis of the survey data focusing on explaining intentions to own a car in the future. We find that there is a significant difference between developing and developed countries; students in developed countries have less desire to purchase cars. Expectations of others appears an important determinant of purchase intentions whereas income and the symbolic affective meaning of the car are less correlated with intentions.
\end{abstract}

Keywords Car ownership motivations $\bullet$ Developed vs developing countries $\bullet$ Attitudes towards cars $\bullet$ Social norms

Prawira Fajarindra Belgiawan (corresponding author) • Jan-Dirk Schmöcker • Satoshi Fujii

Department of Urban Management, Kyoto University, Japan

C1-2-437, Kyoto Daigaku-Katsura, Nishikyo-ku, Kyoto, Japan.615-8540

e-mail: belgiawan@trans.kuciv.kyoto-u.ac.jp

Maya Abou-Zeid

Department of Civil and Environmental Engineering, American University of Beirut, Lebanon

Joan Walker

Department of Civil and Environmental Engineering and the Center for Global Metropolitan Studies, University of California, Berkeley, USA

Tzu-Chang Lee

Department of Urban Planning, National Cheng Kung University, Taiwan

Dick F. Ettema, Ph.D. 
Faculty of Geosciences, Utrecht University, Netherlands

\section{Introduction}

Car ownership levels are increasing rapidly in many developing countries due to rising income levels. In Asia it is not only that former non-vehicle owners can afford to buy cars but also the "upgrade" from motorcycles to cars that causes various traffic and environmental problems. For example, in Indonesia and China this trend towards more and larger vehicles appears to persist despite the lower average speeds of cars compared to motorcycles in the already congested cities and despite the observable environmental side effects (Belgiawan et al. 2012; Zhu et al. 2012). Contrary to this is the discussion on "peak car" in developed countries. Peak car is a hypothesis that travel by passenger vehicles has not grown much recently in a number of the highest income economies, and has even declined, where more income no longer translates into more car travel when income is very high (International Transport Forum 2011). A number of recent studies report reduced car usage of younger people relative to older generations (Kuhnimhof et al. 2013; Van Der Waard et al. 2013). Some cite lifestyle changes as an explanation (Institute for Mobility Research 2013), such as increases in part-time rather than full-time work, living with parents longer, and delaying having children. Understanding car use trends and their underlying factors may be useful for deriving policy measures to reduce the usage of cars.

The aim of this paper is to provide further insight on the reasons for these contrary trends. We do, however, not analyze the trends themselves by time-series or age-cohort data; instead, our focus is on young students in seven different countries and their motivations to purchase cars after graduation. We emphasize the role of personal background and the country context, including prevailing social norms influencing mobility decisions of younger people. We have done this by conducting a survey among undergraduate students from seven different countries. The sites are chosen to cover a wide range of countries (and partly due to previously established research connections).

Four of the sites are from Asia. Indonesia is included as a fast developing country with rapidly increasing motorization among younger people. Taiwan is chosen as a more developed Asian country in which currently the motorbike is the dominating mode among younger people. Shanghai is included 
as a city where the desire to own a car has lately been rapidly increasing especially among younger people (Zhu et al. 2012). Japan is included as a more developed country in which car ownership has been increasing until lately. We further include Beirut, Lebanon, a city in which the car is the dominating mode among all generations. As examples from "Western $1^{\text {st }}$ world countries," we include Utrecht, the Netherlands and Berkeley, U.S.A., two cities with very different mobility patterns and spatial organisation. By conducting the survey in such diverse countries, we aim to make suggestions regarding the causes of differences among the desire to purchase cars among young people.

The structure of this paper is as follows: Section 2 discusses previous research on car ownership forecasting and the motivation of individuals to buy cars. Section 3 focuses on the mobility context in the surveyed countries. Section 4 explains our data collection approach and survey instrument. Section 5 discusses car use and intention reported in the survey. Section 6 describes variables that may explain the intention to buy a car. In section 7 we discuss our findings, and in section 8 we discuss conclusions and implications for transportation planning.

\section{Literature Review}

Generally GDP is considered as a prime indicator of nationwide car ownership levels (Tanner 1978; Kahn and Willumsen 1986; Sillaparcharn 2007). Tanner (1978) proposed an equation for car ownership per person that includes, besides GDP, income per person, population density, growth of population over 10 years, the population proportions under 15 and over 64, and the percentage of self-employed people. Together these factors "explained" 89 percent of the variation in car ownership among countries. However, as Tanner himself noted, these studies have some limitation, in that there is no reason to expect relations of this kind to apply unchanged over long time periods and in particular when saturation is being approached (Tanner 1978).

Other studies on car ownership have been carried out at a disaggregate level to identify factors that affect car ownership decisions of individuals, though more often the focus has been on vehicle type choice (Mannering and Winston 1985; Manski and Sherman 1980).. The models developed in these studies generally consider vehicle attributes (e.g. operating cost, capital cost, and fuel 
efficiency), household characteristics, and principal driver characteristics as explanatory determinants.

Relatively few studies consider psychological determinants, namely attitudes and social norms (e.g., as emphasized in Ajzen 1991). An exception is Steg (2005) who suggests that people do not only drive their cars because it is necessary to do so, but also because they love driving. Her results show that the "status value," also referred to as "symbolic/affective" value of a car, is the most important factor for mode choice decisions followed by instrumental factors (speed, flexibility and convenience) and independence factors.

Van and Fujii (2011) studied attitudes towards private car usage, but not purchase, across six Asian countries and found that attitudinal variables had significant effects on the behavioral intention to commute by car only in Japan, China and Vietnam but not in Indonesia, Thailand and Philippines. They proposed three dimensions of attitudes towards car: Symbolic/affective, Instrumental, and Social Orderliness. The first two factors are in line with Steg (2005) and the latter comprises beliefs such as environmental friendliness, safety, altruism, quietness, etc.

Besides the above studies, our survey is influenced by another stream of literature that suggests that "norming effect" or "influence of others" significantly influences (mobility) decisions. Cialdini et al. (1990) distinguish two types of norms: descriptive and injunctive norms. Descriptive norms refer to the common behavior of others (e.g. the majority choices) whereas injunctive norms refer to one's perceptions of the expectations of others regarding the behavior in question. Studies on the effect of the "influence of others" on vehicle ownership have been mainly discussing "social network structure" and/or controlling the extent of the mass effect (through surveys/experiments) instead of attempting to measure norms (Gaker et al. 2010; Goetzke and Weinberger 2011; Rasouli and Timmermans 2013). Generally, these studies find that the influence of others is significant. For the case of hybrid or electric cars, Oliver and Lee (2010) compare intentions to purchase hybrid cars in South Korea vs. U.S.A. and find that social factors are possibly more influential than environmental factors in both cultures. Abou-Zeid et al. (2013) provide a review of the impact of descriptive norms on a 
wide range of mobility decisions and also conclude that the norming effect cannot be ignored and rather should be used positively by planners.

In conclusion, we believe the literature suggests that the role of norms and attitudes is important in explaining car ownership motivations and that there are some trends of reduced car use and car ownership desire among younger people in developed countries. However, it is not clear whether the same is true in developing countries. These findings motivate our study.

\section{Mobility Context in the Surveyed Countries}

Before describing our survey in more detail, this section provides an overview on the mobility context in the seven countries in which the students were surveyed. Table 1 lists some key factors that describe the motorization level and costs associated with cars in the countries in which we surveyed. The first three columns consist of the three developed countries in our sample, Taiwan is described by IMF as an advanced economic country, and the latter three countries are according to IMF emerging or developing economies (IMF 2013).

In the developed countries, such as the Netherlands, population growth has been minor in the last two decades (UN 2013) while car ownership has increased from 294 cars per 1,000 people in 1990 (Statistics Netherlands 2013) to 406 cars per 1,000 people in 2010 (World Bank 2013). In Japan, the population has been fairly stable over the last decades and is in fact declining since 2010, while car ownership has increased from 286 cars per 1,000 people in 1990 to 458 cars per 1,000 people in 2010 (Oak Ridge National Library 2013). In the U.S.A., the population increased from 254 million in 1990 to 312 million in 2010; however, in contrast to the former two countries, car ownership has declined from 564 cars per 1,000 people in 1990 to 413 cars per 1,000 people in 2010 (Oak Ridge National Library 2013).

Taiwan, with a total population of 23 million people in 2010, also experienced rapid population growth over the past two decades and is one of the densest countries in the world. The passenger car ownership rate in Taiwan at the end of 2010 was 251 cars per 1,000 people, growing from 108 cars per 1,000 people in 1990 (DGBAS 2013). 
Table 1 Context/Statistical Data for the Seven Surveyed Countries

\begin{tabular}{|c|c|c|c|c|c|c|c|}
\hline Variable & Netherlands & Japan & United States & Taiwan & Indonesia & China & Lebanon \\
\hline GDP per capita in 2012, Thousand US\$ & $46,010^{\mathrm{a}}$ & $46,706^{\mathrm{a}}$ & $51,703^{\mathrm{a}}$ & $20,335^{\mathrm{a}}$ & $3,593^{\mathrm{a}}$ & $6,071^{\mathrm{a}}$ & $10,310^{\mathrm{a}}$ \\
\hline $\begin{array}{l}\text { GDP (Purchasing Power Parity) per } \\
\text { capita in 2012, Thousand US } \$\end{array}$ & $41,527^{\mathrm{a}}$ & $35,855^{\mathrm{a}}$ & $51,703^{\mathrm{a}}$ & $38,356^{\mathrm{a}}$ & $4,923^{\mathrm{a}}$ & $9,055^{\mathrm{a}}$ & $15,587^{\mathrm{a}}$ \\
\hline Population 1990 (in Thousands) & $14,890^{\mathrm{b}}$ & $122,249^{b}$ & $254,507^{\mathrm{b}}$ & $20,232^{\mathrm{b}}$ & $178,663^{\mathrm{b}}$ & $1,165,429^{b}$ & $2,703^{\mathrm{b}}$ \\
\hline Population 2010 (in Thousands) & $16,615^{\mathrm{b}}$ & $127,353^{\mathrm{b}}$ & $312,247^{b}$ & $23,146^{\mathrm{b}}$ & $240,676^{\mathrm{b}}$ & $1,359,821^{\mathrm{b}}$ & $4,341^{\mathrm{b}}$ \\
\hline Population density per sq km in 2010 & $400.1^{\mathrm{b}}$ & $337.0^{\mathrm{b}}$ & $32.4^{\mathrm{b}}$ & $639.5^{\mathrm{b}}$ & $126.4^{\mathrm{b}}$ & $141.7^{\mathrm{b}}$ & $417.4^{\mathrm{b}}$ \\
\hline Number of cars per 1,000 people in 1990 & 294 (Stat. Neth. 2013) & $286^{\mathrm{c}}$ & $564^{\mathrm{c}}$ & 108 (DGBAS 2013) & $7^{\mathrm{c}}$ & $2^{c}$ & $\sim 300^{\mathrm{d}}$ \\
\hline Number of cars per 1,000 people in 2010 & 406 (Stat. Neth. 2013) & $458^{\mathrm{c}}$ & $413^{\mathrm{c}}$ & 251 (DGBAS 2013) & $37^{\mathrm{c}}$ & $25^{\mathrm{c}}$ & $\sim 300-500^{\mathrm{d}}$ \\
\hline \multicolumn{8}{|l|}{ Car Ownership and Use Costs (US\$) } \\
\hline Purchase price & $31,693^{\mathrm{e}}$ & $22,613^{\mathrm{e}}$ & $20,000^{\mathrm{e}}$ & $20,422^{\mathrm{e}}$ & $26,908^{\mathrm{e}}$ & $24,640^{\mathrm{e}}$ & $19,000^{\mathrm{e}}$ \\
\hline Fuel price/liter (Super grade gasoline) & $2.33^{\mathrm{f}}$ & $2.00^{\mathrm{f}}$ & $0.97^{\mathrm{f}}$ & $1.18^{\mathrm{f}}$ & $0.47^{\mathrm{f}}$ & $1.37^{\mathrm{f}}$ & $1.11^{\mathrm{f}}$ \\
\hline \multicolumn{8}{|l|}{2011} \\
\hline Fuel price/liter (Diesel) 2011 & $1.95^{\mathrm{f}}$ & $1.61^{\mathrm{f}}$ & $1.05^{\mathrm{f}}$ & NA & $0.47^{\mathrm{f}}$ & $1.28^{\mathrm{f}}$ & $0.94^{\mathrm{f}}$ \\
\hline Mode Choice Pattern & (Utrecht) & & (Berkeley, CA) & & & (Shanghai) & (Beirut) \\
\hline (reference) & $\begin{array}{c}\text { (Statistics Netherlands } \\
\text { 2013) }\end{array}$ & (MLIT 2007) & $\begin{array}{c}\text { (Metropolitan } \\
\text { Transportation } \\
\text { Commission 2006) }\end{array}$ & (DGBAS 2013) & $\begin{array}{c}\text { (Indonesia Central } \\
\text { Agency of Statistics } \\
\text { 2013) }\end{array}$ & $\begin{array}{l}\text { (Urban Construction and } \\
\text { Communications } \\
\text { Commission 2010) }\end{array}$ & (Nakkash 1999) \\
\hline Car & $51 \%$ & $45 \%$ & $81 \%$ & $23 \%$ & $8 \%$ & $20 \%$ & $71 \%$ \\
\hline Public transportation & $25 \%$ & $16 \%$ & $1 \%$ & $15 \%$ & $33 \%$ & $25 \%$ & $29 \%$ \\
\hline Motorcycle & NA & $19 \%$ & $5 \%$ & $48 \%$ & $16 \%$ & $1 \%$ & negligible \\
\hline Other (primarily non-motorized) & $24 \%$ & $20 \%$ & $13 \%$ & $14 \%$ & $44 \%$ & $54 \%$ & NA \\
\hline
\end{tabular}

Reference: a. IMF (2013) b. UN (2012) c. Oak Ridge National Laboratory (2013) d. Ministry of Environment (2011; 2013) e. Numbeo Doo (2013) f. World Bank (2013) 
Indonesia, China, and Lebanon similarly experienced rapid population growth over the past 20 years as well as a rapid increase in car ownership. In Indonesia the number of private cars increased from 7 to 37 cars per 1,000 people in the same time period (Oak Ridge National Library 2013). In China the car ownership rate increased from 2 to 25 cars per 1,000 people between 1990 and 2010 (Oak Ridge National Library 2013) with much higher rates in the large metropolitan areas. In Lebanon, estimates of car ownership range from 1 car for every 3 persons to 1 car for every 2 persons (Ministry of Environment 2011; 2013).

The cost of owning a car and using a car is also shown. The most expensive purchase price is in the Netherlands followed by Indonesia and China with the cheapest in Lebanon (Numbeo Doo 2013). The expensive price of cars in conjunction with purchasing power per capita, partly explains lower car ownership rates especially in Indonesia, even considering low gasoline prices.

Finally, the mode choice patterns are presented for the seven surveyed sites. For Japan, Taiwan, and Indonesia, since the survey was conducted nationwide we present also nationwide data. In Japan the dominant mode share is car at $45 \%$ (MLIT 2007). In Taiwan motorcycle dominates the modal share at $48 \%$ (it has the highest motorbike ownership in the world). In Indonesia public transportation and other modes (primarily non-motorized) dominate the modal share (Indonesia Central Agency of Statistics 2013).

In the other four countries (the Netherlands, U.S.A., China, and Lebanon), our survey only focused on specific cities/regions and we hence show mode choice patterns for these specific areas. Seventy-one percent of trips in the Greater Beirut Area are made by private car (Nakkash 1999). The modal shares in Berkeley (Metropolitan Transportation Commission 2006) and Utrecht (Statistics Netherlands 2013) are dominated by cars. In Shanghai (Urban Construction and Communications Commission 2010) other modes obtain a share of 54\%, where a large percentage of this is walk. These statistics provide a high level picture of the varying transportation conditions and culture at the different sites, and now we move on to the survey results to examine car use with a survey that provides more control over the comparability of results across the sites. 


\section{Data Collection Method}

\section{Respondents}

All respondents are undergraduate students from a wide variety of disciplines. The data were collected between January-June 2013. In all countries the survey was translated into the local language with the exception of Lebanon where the survey was conducted in English, which is the language of instruction at the American University of Beirut (AUB). All responses were gathered via a web-based survey, although the methods to recruit respondents differed in each country.

In Indonesia, surveying agencies recruited respondents in person on the campuses of the Indonesian University in Jakarta and the Bandung Institute of Technology. In Japan, the recruitment was via email sent to engineering departments in several universities. In China, the recruitment was via email and through an internet forum in Shanghai with a small incentive in the form of a mobile phone voucher for those who complete the survey. In Berkeley, recruitment was handled by the Experimental Social Science laboratory, and each respondent received financial incentive for participating. In Lebanon, the recruitment was done via email sent to approximately one third of AUB students (chosen randomly). In the Netherlands, recruitment was done via an announcement in a general student newsletter. In Taiwan, recruitment was done via an announcement in a popular Bulletin Board System (Ptt.cc). No financial incentives were used other than in Shanghai and Berkeley.

In total 2,272 undergraduate and graduate students accessed the survey website, of which 1,806 completed the survey. For better cross-site comparability, we only report in this paper on the data from the undergraduate students. We further performed data cleaning, ignoring incomplete surveys and responses that were completed in fewer than 8 minutes which seems a lower limit to answer all of our survey questions consciously. This results in a sample size of 1,229 used for the analysis below.

\section{Questionnaire Design}

The main objective of the paper is to analyze differences among university students in the seven countries in terms of their stated intentions to buy 
a car in the future (next 10 years), which was measured on a 7-point Likert scale (very unlikely - very likely). In addition, we asked questions about a wide range of possible determinants of car purchase intentions, including questions regarding socio-demographic characteristics, current transportation patterns, attitudes and perceptions, and norms, each of which is expanded on below.

Socio-Demographic Characteristics. We asked students regarding average income (personal and family), age, gender as well as their current living situation, i.e. whether they live by themselves, with their family or friends and, whether they live in a dormitory or apartment.

Current Transportation Patterns. We asked about current transportation patterns including car, bicycle, and motorcycle ownership and how much they use the car for various trip purposes.

Attitudes/Perceptions. We asked 15 questions about the students' attitudes/perceptions toward cars and also public transportation. Each question was posed on a 7-point Likert scale with verbally defined endpoints (strongly disagree - strongly agree). The questions are based on surveys used in previous research in particular those studies by Steg (2005) and Van and Fujii (2011). The questions are listed in Table 4. In the table the questions are grouped by their factor analysis results that are largely in agreement with the results of the aforementioned studies.

Social Norms. We asked a range of questions regarding the influence of others on the students" car purchase intentions. To understand "descriptive norms" we asked respondents about the percentages of family members, close friends, peers, people in their neighborhood, and people in their province/state that have cars. The response categories were: less than 25\%, 25-50\%, 50-75\%, and more than $75 \%$. To measure the perceived "expectation of others to buy a car", respondents were asked "To what extent does each of the following groups (1. Your parents, 2. Your partner, 3. Your family members and relatives, 4. Your close friends, 5. Your classmates, friends and peers at university, 6. People in your neighborhood and 7. People in your province/state) expect you to buy a car within the next 10 years?" Responses to this group of questions were measured on a 7-point Likert scale ranging from "they strongly expect me not to buy a car" to 
"they have no expectation" as middle point and "they strongly expect me to buy a car" as the other end point.

We further measured the "Strength of Influence of others to buy a car" by asking respondents how important the same seven groups are to their decision regarding buying a car in the future. Finally, we aimed to measure subjective social norms or "Perceived pressure to buy a car" by asking respondents to rate their level of agreement with the following statements on a 7-point Likert scale (strongly disagree - strongly agree): "I feel that there is social pressure to have a car here", "Transport modes other than car (walking, bike and public transport) are looked down upon", and "The majority of people think that having a car is the right thing to do."

\section{Peak Car Indices and Mobility Patterns in Our Sample}

Our aim is to explain variables of interest for the peak car discussion with the available sets of possible explanatory variables. Table 2 describes the past, current, and potential future car ownership and car usage situations of students as reported in the survey.

In all sites more than $90 \%$ of students grew up with a car in the household except for Indonesia and Shanghai, illustrating how prevalent the car has been for most students not only in the most developed countries but also Taiwan and Beirut. We then have a number of indices that describe the current mobility pattern. We define a car owner as a student who owns a car personally or who has regular access to his/her family car. In all cases, the majority of these “car owning" students (70-90\%) are using family cars. The exception is Beirut where one-third of "car-owning" students have their own car. Interesting to note is that the difference between current student car owners and those who grew up with a car is much more significant in developed countries (average car user and owner below $30 \%$ ) compared to developing countries (average car user and owner above 50\%). As expected, the percentage of car users (using a car at least two days per week) is slightly higher than the percentage of car owners for all countries. 
Noteworthy in Beirut and Indonesia are the smaller differences between the percentage of students who grew up with a car at home and the percentage using a car now regularly, whereas in the "1st world" samples from Japan, Berkeley, and Utrecht the difference is very significant. The difference in Taiwan might be explained partly by the reliance on motorcycles.

Table 2 Car Ownership, Use, and Intention: Past, Present, and Future

\begin{tabular}{|c|c|c|c|c|c|c|c|}
\hline $\begin{array}{c}\text { Variable } \\
\text { (number of observations) }\end{array}$ & $\begin{array}{l}\text { Utr } \\
(84)\end{array}$ & $\begin{array}{c}\text { Jpn } \\
(142)\end{array}$ & $\begin{array}{l}\text { Brkly } \\
(226)\end{array}$ & $\begin{array}{l}\text { Twn } \\
(139)\end{array}$ & $\begin{array}{c}\text { Idn } \\
(200)\end{array}$ & $\begin{array}{l}\text { Sgh } \\
(167)\end{array}$ & $\begin{array}{c}\mathrm{Brt} \\
(271)\end{array}$ \\
\hline \multicolumn{8}{|l|}{ Past: } \\
\hline Grew up with car (\% Yes) & 96.4 & 95.1 & 97.3 & 90.6 & 76.5 & 30.5 & 97.8 \\
\hline \multicolumn{8}{|c|}{ Present: Ownership \&Transportation Pattern } \\
\hline Car User $(\%)$ & 27.4 & 26.1 & 48.2 & 41.0 & 64.5 & 28.7 & 89.7 \\
\hline Car user \& owner $(\%)$ & 21.4 & 23.9 & 31.4 & 38.8 & 56.5 & 26.3 & 85.6 \\
\hline Car user \& non-owner $(\%)$ & 6.0 & 2.2 & 16.8 & 2.7 & 8.0 & 2.4 & 4.1 \\
\hline Non-Car User (\%) & 72.6 & 73.9 & 51.8 & 59.0 & 35.5 & 71.3 & 10.3 \\
\hline Motorcycle Owner (\%) & 0 & 15.5 & 0.9 & 68.3 & 51.5 & 2.4 & 4.1 \\
\hline Motorcycle or Car Owner (\%) & 21.4 & 33.8 & 31.9 & 79.9 & 78 & 27.5 & 86 \\
\hline Driving license (\% have) & 71.4 & 60.6 & 80.5 & 77.7 & 74 & 27.5 & 80.1 \\
\hline Mileage per week (Av. km) & 62.8 & 111.5 & 56.5 & 76.4 & 69.4 & 71.2 & 77.3 \\
\hline Bicycle (\% have) & 98.8 & 88 & 27.9 & 66.2 & 51 & 69.5 & 28 \\
\hline \multicolumn{8}{|l|}{ Mode of commuting } \\
\hline Car $(\%)$ & 2.4 & 6.3 & 4.9 & 5.8 & 28.0 & 5.4 & 60.9 \\
\hline Motorcycle (\%) & 0 & 7.7 & 0.4 & 41.0 & 24.0 & 0.0 & 1.1 \\
\hline Public Transportation (\%) & 42.8 & 27.4 & 17.2 & 33.7 & 33.0 & 59.3 & 17.4 \\
\hline Bicycle (\%) & 51.2 & 52.8 & 7.1 & 13.7 & 1.0 & 7.8 & 0.7 \\
\hline Walk $(\%)$ & 3.6 & 5.8 & 70.4 & 5.8 & 14.0 & 27.5 & 19.9 \\
\hline \multicolumn{8}{|c|}{ Future: Purchase Intentions (How likely are you to buy a car within the next 10 years?) } \\
\hline$\%$ have intention & 61.9 & 62.7 & 65.9 & 66.9 & 67.5 & 77.2 & 83.8 \\
\hline Very likely & 9.5 & 17.6 & 21.7 & 14.4 & 18.5 & 26.9 & 38.0 \\
\hline Likely & 10.7 & 18.3 & 25.7 & 15.8 & 36.5 & 31.1 & 28.0 \\
\hline Somewhat likely & 41.7 & 26.8 & 18.6 & 36.7 & 12.5 & 19.2 & 17.7 \\
\hline$\%$ have no intention & 38.1 & 37.3 & 34.1 & 33.1 & 32.5 & 22.8 & 16.2 \\
\hline Undecided & 15.5 & 11.3 & 10.2 & 24.5 & 20.5 & 10.8 & 5.2 \\
\hline Somewhat unlikely & 11.9 & 7.0 & 9.7 & 5 & 8.0 & 6.6 & 4.1 \\
\hline Unlikely & 7.1 & 9.9 & 9.7 & 3.6 & 3.0 & 2.4 & 3.3 \\
\hline Very unlikely & 3.6 & 9.2 & 4.4 & $N A$ & 1.0 & 3.0 & 3.7 \\
\hline
\end{tabular}

In general, the current car ownership and use as well as driving license statistics are in line with our expectations. Students in Utrecht are frequent bicycle users, Beirut students heavily rely on private cars, and Taiwanese students heavily 
rely on motorbikes. Utrecht figures can also be understood from the fact that many students live independently in the city of Utrecht and use their bikes to commute to the university. Those who live with their parents and commute longer distances often use their transit pass that is provided to all students.

Finally, we report in Table 2 future car ownership intentions. We show the responses to our 7 point scale and further convert here in addition the answers into a binary scale by interpreting answers from 1 to 4 as "have no intention" and 5 to 7 as "have intention". (In the following tables we return to the 7-point scale). More than $60 \%$ of students in all countries have an intention to buy a car in the future. As this is the dependent variable of interest, we have ordered this table as well as all other tables in the paper based on this auto intention response. The order of intention to own a car sorts our countries precisely into developed vs. developing countries with Taiwan being in between the two groups. Students in Utrecht, Japan, and Berkeley have the lowest car purchase intentions; and students in Indonesia, Shanghai, and Beirut have the highest. This is consistent with the peak auto hypothesis of the developed world as well as increasing auto dependency in the developing world.

\section{Potential Determinants of Car Ownership Intention}

In this section we present descriptive statistics for the three categories of possible determinants discussed above: socio-demographic characteristics, attitudes/perceptions, and norms. In the next section, we examine how these categories of variables, plus current transportation patterns, are correlated with the intention to buy a car.

Table 3 summarizes the socio-demographic characteristics of each site. In terms of living arrangement, the majority of students in Indonesia and Beirut and a substantial proportion in Japan and Taiwan live with their families whereas a significantly lower proportion of students live with their families in Shanghai, Berkeley, and Utrecht. The average age of students in the sample is between 19-21. In terms of gender, the Japanese, Taiwanese, and Shanghai samples are unbalanced, which is a result of the recruitment methods.

Average personal monthly income (converted into US\$) is, as expected, lowest among Indonesian students while the students with the highest income are 
those from Utrecht followed by Berkeley and Beirut students. Considering average family income, we find that families of Berkeley students are the wealthiest followed by families of students in Japan and Beirut and then in Utrecht. Taiwanese and Shanghai families have a significantly lower income, and Indonesia the lowest.

Table 3 Socio-Demographic Characteristics in the Seven Surveyed Sites

\begin{tabular}{|c|c|c|c|c|c|c|c|}
\hline $\begin{array}{c}\text { Variable } \\
\text { (number of observations) }\end{array}$ & $\begin{array}{l}\text { Utr } \\
(84)\end{array}$ & $\begin{array}{c}\text { Jpn } \\
(142)\end{array}$ & $\begin{array}{l}\text { Brkly } \\
(226)\end{array}$ & $\begin{array}{l}\text { Twn } \\
\text { (139) }\end{array}$ & $\begin{array}{l}\text { Idn } \\
(200)\end{array}$ & $\begin{array}{l}\text { Sgh } \\
(167)\end{array}$ & $\begin{array}{c}\text { Brt } \\
(271)\end{array}$ \\
\hline \multicolumn{8}{|c|}{ Socio-Demographic Characteristics } \\
\hline \multicolumn{8}{|l|}{ Living Arrangement } \\
\hline Living Alone (\%) & 6.0 & 55.6 & 4.4 & 13.7 & 24.0 & 2.4 & 5.5 \\
\hline Living with Family (\%) & 23.8 & 41.5 & 14.2 & 45.3 & 58.0 & 12.0 & 77.1 \\
\hline Living with Friends (\%) & 63.1 & 2.1 & 75.2 & 36.0 & 17.6 & 80.8 & 10.7 \\
\hline Other $(\%)$ & 7.1 & 0.8 & 6.2 & 5.0 & 0.4 & 4.8 & 5.7 \\
\hline \multicolumn{8}{|l|}{ Dwelling Unit } \\
\hline Dormitory $(\%)$ & 22.6 & 7.7 & 5.8 & 36.0 & 6.5 & 89.2 & 11.8 \\
\hline Apartment (\%) & 41.7 & 54.9 & 68.1 & 34.5 & 3.0 & 4.8 & 50.2 \\
\hline Other $(\%)$ & 35.7 & 37.4 & 26.1 & 29.5 & 90.5 & 6.0 & 38.0 \\
\hline Av. Age & 21.6 & 20.0 & 20.3 & 21.7 & 20.5 & 21.1 & 19.7 \\
\hline Gender split (\% male) & 54.8 & 77.5 & 50.4 & 72.6 & 51.5 & 59.9 & 45.4 \\
\hline Av. personal income (US \$)* & 792 & 307 & 620 & 295 & 86 & 226 & 535 \\
\hline Av. family income (US \$)* & 5,981 & 6,471 & 7,395 & 3,369 & 824 & 1,119 & 6,435 \\
\hline
\end{tabular}

* based on income group range measured with local currency; ANOVA significant for all variables

To better understand "emotional attachment" of students to cars, we analyze our attitudinal questions and group these with a principal component analysis (PCA). In Table 4 we report (in parentheses) the loading of the items in the factors in which they load highest. Based on varimax rotation, four factors with eigen values larger than one could be extracted. Table 4 shows the mean values of the responses to the attitude/perception statements loading on the different factors (as well as norm statements in the lower part of the table). These factors are consistent with findings in the literature: Symbolic Affective (explaining 22.3\% of the variance) (Steg, 2005; Van and Fujii, 2011), Independent (16.1\% of the variance) (Steg, 2005), Negative Aspects of car (9.9\% of the variance) (Zhu et al., 2012), and Social Orderliness (9.4\% of the variance) (Van and Fujii, 2011). The difference in the single questions as well as the country specific factors is statistically significant according to ANOVA analysis. 
Table 4 Mean Values of Responses to Attitude/Perception/Norm Statements Loading on the Different Factors in the Seven Surveyed Sites

\begin{tabular}{|c|c|c|c|c|c|c|c|c|c|}
\hline \multirow{2}{*}{ Factor } & \multirow{2}{*}{ Variable (Factor loading) } & All & Utht & Jpn & Bkly & Twn & Idn & Sgh & Brt \\
\hline & & 1229 & 84 & 142 & 226 & 139 & 200 & 167 & 271 \\
\hline \multicolumn{10}{|c|}{ Attitudes/perceptions toward car. Respondents were asked whether Cars ... } \\
\hline Symbolic Affective & $\begin{array}{l}\ldots \text { allow to distinguish oneself from others }(0.78), \ldots \text { are trendy }(0.75), \ldots \text { bring prestige }(0.74), \ldots \text { are } \\
\text { cool }(0.70), \ldots \text { allow to express oneself }(0.70), \ldots \text { are fun to have }(0.66)\end{array}$ & 4.39 & 3.71 & 3.73 & 4.66 & 4.49 & 4.70 & 4.29 & 4.52 \\
\hline Independent & $\begin{array}{l}\ldots \text { are convenient }(0.80), \ldots \text { give freedom to travel anytime }(0.79), \ldots \text { help one to save time when making a } \\
\text { trip }(0.75), \ldots \text { are useful to pick up or drop off others }(0.54)\end{array}$ & 5.76 & 5.92 & 5.83 & 6.16 & 5.63 & 5.03 & 5.86 & 5.86 \\
\hline Negative Aspects & $\begin{array}{l}\ldots \text { are expensive to own and maintain }(0.71), \ldots \text { are disturbing one's neighborhood }(0.67) \text {, } \\
\text { giving an arrogant impression }(0.60)\end{array}$ & 4.29 & 4.32 & 4.41 & 4.07 & 4.37 & 4.27 & 4.14 & 4.49 \\
\hline Social Orderliness & ....allow one to travel safely $(0.81), \ldots$ are environmentally friendly $(0.78)$ & 3.94 & 3.71 & 4.12 & 3.80 & 4.61 & 4.24 & 4.03 & 3.41 \\
\hline \multicolumn{10}{|c|}{ Attitudes/perceptions toward public transportation $(P T)$} \\
\hline Safety and Reliability & $\begin{array}{l}\text { The drivers drive carelessly }(0.84) \text {, I feel unsafe using public transport }(0.83) \text {, The service is unreliable } \\
(0.61) \text {, I get annoyed by long waiting times at stops }(0.61)\end{array}$ & 4.11 & 3.12 & 3.17 & 3.96 & 4.15 & 5.25 & 3.64 & 5.52 \\
\hline Convenience & $\begin{array}{l}\text { The service covers the city area well }(0.85) \text {, The service is efficient }(0.80) \text {, The service is convenient } \\
(0.76)\end{array}$ & 4.15 & 4.85 & 4.08 & 4.71 & 4.21 & 3.24 & 4.52 & 3.39 \\
\hline \multicolumn{10}{|l|}{ Social Norms } \\
\hline \multicolumn{2}{|c|}{ Descriptive Norms (Perceived Car Usage Frequency of Others) (Cronbach’s Alpha = 0.72) } & 2.63 & 2.40 & 2.48 & 2.92 & 2.39 & 2.64 & 1.92 & 3.08 \\
\hline \multicolumn{2}{|c|}{ Expectation of Others to Buy a car (Cronbach's Alpha $=0.92)$} & 4.63 & 3.39 & 4.80 & 4.83 & 4.86 & 4.75 & 4.66 & 5.10 \\
\hline \multicolumn{2}{|c|}{ Strength of Influence of Others to Buy a Car (Cronbach’s Alpha = 0.85) } & 4.41 & 3.70 & 5.01 & 4.16 & 4.52 & 4.85 & 4.64 & 3.98 \\
\hline \multicolumn{2}{|c|}{ Subjective Social Norms (Perceived pressure to buy a car) (Cronbach's Alpha = 0.72) } & 3.76 & 2.85 & 3.52 & 3.64 & 3.59 & 3.75 & 4.02 & 4.95 \\
\hline
\end{tabular}

ANOVA significant for all variable 
For symbolic affective, the lowest ratings are those of Utrecht and Japan, which indicates that the car is not perceived as bringing social status in these locations compared to the other countries. For independent, the highest overall rating comes from Berkeley followed by Utrecht, Beirut, and Shanghai. Indonesia and Taiwan have the lowest rating, except the variable "cars are useful to pick up or drop off others". This might link to their intensive use of motorcycles, which offer more convenience, freedom, and saving of travel time than cars do.

In terms of negative aspects, the rating of the "cars give an arrogant impression" is highest in Beirut and Indonesia, the two countries in our sample in which, arguably, students most need to rely on cars for daily activities. An explanation might be envy among those who cannot afford to buy a car as well as the "misuse" of the car as a status symbol of a few among the students who purchase large, expensive cars. In terms of social orderliness, students in all countries tend to disagree that the car is environmental friendly, with the lowest rating given by the Beirut sample, where the transportation sector is responsible for high levels of emissions, which are well beyond standards prescribed by the World Health Organization.

To complement our analysis of attitudes/perceptions towards cars, we asked students about their attitudes/perceptions towards public transportation (PT) and also here conduct a principal component analysis from which we extract two factors that we refer to as "safety and reliability" and "convenience". Also here we find with ANOVA analysis that the PT perceptions of both factors are distinct in all seven countries. The low quality of the public transportation system in Indonesia and Beirut is reflected in the students' ratings of the system attributes. Utrecht students report the highest ratings of PT.

In addition to attitudes/perceptions, we investigate the role of norms. The descriptive norm ratings are a reflection of the perceived current car ownership situation in the countries, with higher values denoting higher perception of auto ownership. Beirut in this case is the highest, followed by Berkeley. Shanghai is lowest. Expectation of others is related to the perceived status value of a car as well as the general perceived need to own a car. In Utrecht the value is understandably significantly lower than in other samples. Slightly surprising is the high perceived expectation of others for students to buy a car in 
Japan and Berkeley. "Strength of influence of others" might be seen as a measure of "independence". Here we find again the lowest rating for the Dutch students possibly reflecting a "more independent Western mindset".

Finally, regarding subjective social norms, the high and low values in Beirut and Utrecht are understandable given the afore discussed context. Utrecht has a good transit system and progressive transportation policies, and using the bicycle for commuting is common (51.2\% reported in Table 2). Noteworthy are the relatively high values in Indonesia and Shanghai. Together with previous results this might suggest that owning a car is perceived as something one should be able to afford even if "showing the car to others" (as status symbol) is not necessarily a main purpose.

\section{Intention to Buy a Car In The Future}

Given the possible explanatory factors discussed in the previous section, in this section we aim to relate these variables to car purchase intentions. Table 5 shows the mean intentions of car owners to purchase a new/different car and the intentions of non-car owners to purchase a car within the next 10 years. We can observe stronger intentions to buy a car among the students in developing countries, and the difference between them and the developed countries is significant (t-test= 7.19; not shown in the table), possibly partly reflecting the higher relative price of cars when considering income and hence that these students cannot yet afford cars. An additional explanation may be found in the quality of public transportation in Japan and the Netherlands, especially in the urban areas where the current student will likely reside when starting to work. We can further observe that current car owners have a stronger intention to remain car owners than the desire of current non-owners to purchase a car. This is the case irrespective of geography though the difference is only significant in Japan, Beirut and Berkeley. 
Table 5 Likelihood to Buy a Car in the Future

\begin{tabular}{|c|c|c|c|c|c|c|c|}
\hline $\begin{array}{c}\text { Variable } \\
\text { (number of observations) }\end{array}$ & $\begin{array}{l}\text { Utr } \\
(84)\end{array}$ & $\begin{array}{c}\text { Jpn } \\
(142)\end{array}$ & $\begin{array}{l}\text { Brkly } \\
(226)\end{array}$ & $\begin{array}{l}\text { Twn } \\
(139)\end{array}$ & $\begin{array}{c}\operatorname{Idn} \\
(200)\end{array}$ & $\begin{array}{l}\text { Sgh } \\
(167)\end{array}$ & $\begin{array}{c}\text { Brt } \\
(271)\end{array}$ \\
\hline All Sample Means & 4.55 & 4.62 & 4.92 & 4.99 & 5.24 & 5.42 & 5.65 \\
\hline (Sd.D) $\quad$ ANOVA $=0.00$ & (1.47) & $(1.86)$ & $(1.79)$ & $(1.23)$ & $(1.41)$ & $(1.51)$ & $(1.57)$ \\
\hline Car owner Means & 5.00 & 5.15 & 5.45 & 5.13 & 5.33 & 5.48 & 5.74 \\
\hline (Sd.D) $\quad$ ANOVA $=0.02$ & $(1.68)$ & $(1.52)$ & $(1.52)$ & $(1.40)$ & $(1.37)$ & $(1.47)$ & (1.53) \\
\hline Non-car owner means & 4.42 & 4.45 & 4.68 & 4.90 & 5.13 & 5.40 & 5.18 \\
\hline (Sd.D) $\quad$ ANOVA $=0.00$ & (1.39) & $(1.95)$ & $(1.86)$ & $(1.10)$ & $(1.48)$ & $(1.54)$ & (1.76) \\
\hline $\begin{array}{l}\text { Independent t-test car owner and } \\
\text { non-car owner }\end{array}$ & -1.49 & $-2.16 *$ & $-3.28 *$ & -1.043 & -0.99 & -0.3 & $-2.08 *$ \\
\hline \multicolumn{8}{|c|}{ Correlations between Variables and Intention to Buy a Car In The Future } \\
\hline Symbolic Affective (Car) & 0.08 & $0.23 *$ & $0.24 *$ & $0.26 *$ & 0.03 & 0.07 & $0.21 *$ \\
\hline Independence (Car) & $0.34 *$ & $0.23 *$ & $0.27 *$ & 0.13 & 0.16 & $0.21 *$ & $0.19 *$ \\
\hline Negative Aspects (Car) & -0.32 & 0.09 & -0.09 & 0.08 & -0.1 & -0.14 & -0.11 \\
\hline Social Orderliness (Car) & 0.26 & 0.05 & 0.04 & $0.26 *$ & 0 & 0.12 & 0.09 \\
\hline Safety and Reliability (-) (PT) & 0.05 & 0.05 & $0.21 *$ & 0.20 & 0.02 & 0.12 & 0.11 \\
\hline Convenience (PT) & -0.21 & -0.06 & -0.07 & -0.05 & -0.01 & -0.09 & -0.07 \\
\hline Descriptive Norms & $0.34 *$ & 0.20 & 0.07 & 0.20 & 0.04 & 0.08 & 0.04 \\
\hline Expectation of Others to Buy a & -0.2 & $0.25 *$ & $0.47 *$ & $0.42 *$ & 0.14 & $0.23 *$ & 0.18 \\
\hline \multicolumn{8}{|l|}{ Car } \\
\hline Influence of Others to Buy a Car & 0.12 & 0.19 & 0.20 & 0.07 & 0.06 & 0.05 & $0.35 *$ \\
\hline Subjective Social Norms & 0.1 & 0.1 & $0.22 *$ & 0.20 & -0.11 & 0.03 & 0.12 \\
\hline Av. Age & 0 & 0.02 & 0.01 & 0.17 & 0.09 & 0.08 & -0.01 \\
\hline Av. Income & 0.13 & -0.19 & 0.02 & $0.28 *$ & -0.06 & 0.07 & 0.18 \\
\hline Av. Family income & 0.08 & $0.23 *$ & $0.24 *$ & 0.26* & 0.03 & 0.07 & $0.21 *$ \\
\hline \multicolumn{8}{|c|}{ Categorical Variable (ordinal regression with one variable only) } \\
\hline Gender (male) & 0.3 & -0.1 & -0.03 & 0.55 & 0.3 & -0.08 & -0.23 \\
\hline Driving License (have) & -0.13 & 0.24 & 0.28 & 0.58 & -0.04 & 0.51 & -0.11 \\
\hline Regular Car Use (regular user) & 1.01 & 0.73 & 1.04 & 0.31 & -0.66 & 0.13 & 0.98 \\
\hline Car Ownership (car owner) & 1.02 & 0.56 & 0.75 & 0.37 & 0.23 & 0.07 & 0.68 \\
\hline $\begin{array}{l}\text { Motorcycle or Car Ownership } \\
\text { (motorcycle or car owner) }\end{array}$ & 1.02 & 0.47 & 0.80 & 0.99 & 0.3 & 0.15 & 0.60 \\
\hline $\begin{array}{l}\text { Motorcycle Ownership } \\
\text { (motorcycle owner) }\end{array}$ & NA & 0.22 & 1.05 & 0.55 & -0.05 & 1.37 & -0.55 \\
\hline $\begin{array}{l}\text { Bicycle Ownership (bicycle } \\
\text { owner) }\end{array}$ & -1.87 & 0.53 & -0.07 & -0.09 & 0.35 & 0.45 & 0.06 \\
\hline
\end{tabular}

Italic $\mathrm{p}$ value $<0.1 ;$ Bold $\mathrm{p}$ value $<0.05 ;$ Bold $+* \mathrm{p}$ value $<0.01$

In the lower half of Table 5, we correlate car purchase intentions, regardless of current ownership status, with the various possible explanatory 
factors discussed in Section 5. We note that we find various location specific differences in terms of significance of correlation. It appears most difficult to explain car ownership in Indonesia where we find that only regular car usage and the independence factor explain car ownership intention. Even income appears not to be a good explanatory factor for car purchase intentions in Indonesia (consistent with Zhu et al 2012). We find that among our attitudinal constructs, the symbolic affective factor is significant in various countries, though it is difficult to explain the observed pattern.

Students in Utrecht appear most impacted among the students of the seven study sites by the negative car aspects (environmental impacts, costs of maintenance, arrogant image) in their desire to purchase a car. All countries show a positive significant correlation between independence and the intention to buy a car in the future except for Taiwan. The reason is likely to be that Taiwanese students have long enjoyed the mobility and freedom that motorbikes bring to them.

Further interesting to note is that the perception of public transportation is only associated with car purchase intentions in Berkeley and Taiwan. The Taiwanese students might believe that a good PT system could replace the need for a car after experiencing the successful PT in Taipei. In other countries, the perception of PT might be too uniform to detect a correlation with car purchase intentions.

Another significant finding is the relatively large correlations for the expectation of others regarding car purchase in several samples, in particular Berkeley and Taiwan. In all samples, except Utrecht, we find in fact a stronger significance of perceived expectations than of descriptive norms, i.e. the perceived general car ownership level. In general, we find that norms other than descriptive norms appear less significant among the Dutch students, probably related to a different status of car ownership as discussed previously.

\section{Conclusions}

Our objective was to provide insight on the role of personal background and country contexts including prevailing social norms influencing mobility decisions. Our results contribute to the peak car discussion and complement findings on 
lifestyle changes of younger generations that potentially influence the desire to own a car.

We report survey results of undergraduate students in seven different countries, asking a wide range of questions, including attitudes and norms, and correlate these with stated future car purchase intentions. In terms of intention to buy cars, there is a significant difference between developing and developed countries with students in developed countries having less desire to purchase cars. While income levels partially explain purchase intension, several other factors also had positive correlations, such as Symbolic Affective and Independence car attitudes. On the other hand, attitudes/perceptions towards public transit are not very correlated with auto purchase intention.

Also noteworthy is that Taiwanese students appear in some points different from our other samples probably due to the tradition of motorcycle usage. In the same way that cycling is an established mode in the Netherlands, this shows that the prevailing "mobility culture" is an important factor when considering global trends. From our Taiwanese sample, we might also learn the importance of family bonds when predicting car mileage developments in other Asian countries. Low car ownership does not necessarily translate into low mileage in these countries due to family car sharing.

For most samples there is a strong role of expectation of others for the intention to buy a car in the future. We do not find though a systematic difference between developing and developed countries, suggesting that the effect of others on purchase decisions needs to be studied carefully across countries. In line with this, parents' income is a significant determinant of car purchase intentions in a number of countries, predominantly the more developed ones. The exception is Utrecht, where students in general appear to be the most independent and also perhaps "the most considerate" as they appear to take into account negative aspects of car ownership including environmental aspects. Compared to Asia and the U.S.A., Utrecht has a longer tradition of a good developed public transportation system as well as the discussion on health and environmental benefits of alternative modes. This might also be positive news as such benefits might be seen more in other countries in the future given the focus on sustainability in many countries. 
One might argue that current intentions do not necessarily reflect future car purchases, especially given that lifestyles are likely changing after graduation. We therefore do not claim that our findings should be directly translated into regression models that are used for demand forecasting even for this cohort. Nevertheless, we believe that current intentions are one important determinant explaining future purchases. In support of this argument, literature such as Lanzendorf (2003), Simma and Axhausen (2003 or Millstein et al (1990) argues that travel experiences and habits (which transform into intentions) during young age determine travel patterns during adulthood.

There are many future directions for this work. Differences in sampling methods across the study sites may contribute to potential self-selection biases that we were not able to check for in this study. More representative samples are needed in future research, including from different cultures. The analysis may also be extended to population segments other than students. While our current analysis is based on descriptive and correlation analysis only, future research will apply more advanced statistical modeling. Finally, and as mentioned above, while this study analyzed the intentions to own a car in the future, it is unclear to what extent there will be a gap between these intentions and the actual car purchase decisions. Future analyses will therefore examine current car ownership and use decisions, as well as examine both daily travel patterns and long distance recreational travel to better capture the extent of changes in car use in both developed and developing countries.

While "explorative," this study made use of a detailed, individual level, cross-cultural survey of a wide variety of drivers of auto use and provided insight into the cultural differences and future trends of auto ownership.

Acknowledgements The authors would like to thank Lotte International Scholarship Foundation for supporting this study through a personal scholarship to the first author of this paper as well as UC Berkeley Global Metropolitan Studies, the National Science Foundation, and the Dean's office of the Faculty of Engineering and Architecture at AUB for supporting this work. We also kindly acknowledge the help of Mr. Zhang Dong, Tongji University with data collection in China.

\section{References}


Abou-Zeid, M., Schmöcker, J.-D., Belgiawan, P.F., Fujii, S.: Mass effects and mobility decisions. Transportation Letters: the International Journal of Transportation Research 5(3), 115-130 (2013)

Ajzen, I.: The theory of planned behavior. Organizational Behavior and Human Decision Processes 50(2), 179-211 (1991)

Belgiawan, P.F., Schmöcker, J-D., Fujii, S.: Explaining the desire to own a car among Indonesian students. In Proceedings of the 32nd Japan Society of Traffic Engineers Conference. CD ROM. Japan Society of Traffic Engineers, Tokyo, 259-266 (2012)

Cialdini, R. B., Reno, R. R., Kallgren, C. A.: A focus theory of normative conduct: recycling the concept of norms to reduce littering in public places. Journal of Personality and Social Psychology, 58, 1015-1026 (1990)

Directorate-General of Budget, Accounting and Statistics, Taiwan (DGBAS).: National Statistics. http://eng.stat.gov.tw/mp.asp?mp=5. (2013) Accessed 10 July 2013.

Gaker, D., Zheng, Y., Walker, J.: Experimental economics in transportation: focus on social influences and provision of information. Transp. Res. Rec. 2156, 47-55 (2010)

Goetzke, F., Weinberger, R.: Separating contextual from endogenous effects in automobile ownership models. Presented at the $90^{\text {th }}$ Annual Meeting of the Transportation Research Board, Washington, D.C. (2011)

Indonesia Central Agency of Statistics. Number of motor vehicles by types, Indonesia 1987-2011. http://www.bps.go.id/eng/tab_sub/view.php?kat=2\&tabel=1\&daftar=1\&id_subyek=17\&n otab=12. (2013) Accessed 30 April 2013.

Institute for Mobility Research.: 'Mobility Y' the emerging travel patterns of generation $\mathrm{Y}$. Designed by Hillert und Co. Werbeagentur GmbH. Munich (2013)

International Monetary Fund (IMF):: World Economic Outlook Database October 2013 Edition. http://www.imf.org/external/pubs/ft/weo/2013/02/weodata/index.aspx, (2013) Accessed 12 November 2013

International Transport Forum.: Transport Outlook: Meeting the Needs of 9 Billion People. OECD/ITF., Paris (2011)

Khan, A., Willumsen, L.G.: Modeling car ownership and use in developing countries. Traffic Engineering and Control 27(11), 554-60 (1986)

Kuhnimhof, T., Zumkeller, D., Chlond, B.: Who made peak car, and how? a breakdown of trends over four decades in four countries. Transport Reviews: A Transnational Transdisciplinary Journal 33(3), 325-342 (2013) doi:10.1080/01441647.2013.801928

Lanzendorf, M.: Mobility biographies: a new perspective for understanding travel behaviour. Paper presented at the 10th international conference on travel behaviour research, Lucerne, 10-15 August (2003)

Mannering, F., Winston, C.: A dynamic empirical analysis of household vehicle ownership and utilization. Rand Journal of Economics 16(2), 215-236 (1985)

Manski, C. F., Sherman, L.: An empirical analysis of household choice among motor vehicles. Transp. Res. Part A 14(5-6), 349-366 (1980) 
Metropolitan Transportation Commission.: San Francisco Bay Area Regional Demographic and Travel Characteristics, 2006. http://www.mtc.ca.gov/maps_and_data/datamart/stats /baydemo.htm. (2013) Accessed 20 July 2013

Millstein, S.G., Litt, I.: Adolescent health and health behaviors, S.S. Feldman, G. Elliott, Editors. At the threshold: The developing adolescent, Harvard University Press, Cambridge, MA 431-456 (1990)

Ministry of Environment.: Lebanon's Second National Communication to the United Nations Framework Convention on Climate Change. Beirut, Lebanon (2011)

Ministry of Environment.: Part A4 Transport Sector, Technical Annex to Lebanon's First National Communication. Beirut, Lebanon. http://www.moe.gov.lb/ClimateChange/Climate2/. (2013) Accessed 17 July 2013.

Ministry of Land, Infrastructure and Transport Japan (MLIT).: Results from the $4^{\text {th }}$ Nationwide Person Trip Survey <Press Release>. Urban Transportation Planning Division, City and Regional Development Bureau, MLIT, Japan, (2007)

Nakkash, T.: Transport Plan for Greater Beirut. In: Baaj, M.H. (ed.), Proceedings of the Workshop on Land Transport Policy for Lebanon. Prepared for Lebanon Ministry of Transport, (1999)

Numbeo Doo.: Cost of Living 2013. http://www.numbeo.com/cost-of-living/ (2013) Accessed 24 October 2013.

Oak Ridge National Laboratory.: Transportation energy data book: chapter 3 all highway vehicles and characteristics, Table 3.2. Car Registrations for Selected Countries, 1950-2011. http://cta.ornl.gov/data/tedb32/Spreadsheets/Table3_02.xls. (2013) Accessed 14 November 2013.

Oliver, J.D., Lee, S.-H.: Hybrid car purchase intentions: a cross-cultural analysis. Journal of Consumer Marketing 27(2), 96-103 (2010)

Rasouli, S. and Timmermans, H.: The effect of social adoption on the intention to purchase electric cars: a stated choice approach. Presented at the $92^{\text {nd }}$ Annual Meeting of the Transportation Research Board, Washington, D.C. (2013)

Sillaparcharn, P.: Modeling of vehicle ownership: case study of Thailand. Transp. Res. Rec. 2038, 98-104 (2007)

Simma, A., Axhausen, K.W.: Commitments and modal usage: analysis of German and Dutch panels. Transp. Res. Rec. 1854, 22-31(2003)

Statistics Netherlands. Motor vehicles; general overview per period and technological features. http://www.cbs.nl/en-GB/menu/themas/verkeer-vervoer/cijfers/default.htm Accessed 12 November 2013.

Steg, L.: Car use: lust and must. Instrumental, symbolic and affective motives for car use. Transp. Res. Part A 39, 147-162 (2005)

Tanner, J.C.: Long term forecasting of vehicle ownership and road traffic (with discussion). Journal of the Royal Statistical Society, Series A, 14, 14-63 (1978) 
United Nations, Department of Economic and Social Affairs.: World Population Prospects: The 2012 Revision, http://esa.un.org/wpp/Excel-Data/population.htm, (2013) Accessed 12 November 2013

Urban Construction and Communications Commission.: Report of $4^{\text {th }}$ Comprehensive Transportation Survey of Shanghai. Shanghai Urban Construction and Communications Commission (2010)

Van, H.T., Fujii, S.: A cross Asian country analysis in attitudes toward car and public transport. Journal of the Eastern Asia Society for Transportation Studies 9, 411-421 (2011)

Van Der Waard, J., Jorritsma, P., Immers, B.: New drivers in mobility; what moves the Dutch in 2012? Transport Reviews: A Transnational Transdisciplinary Journal 33(3), 345-359 (2013) doi: 10.1080/01441647.2013.801046

World Bank.: Passenger cars per 1.000 people 2010, World Development Indicators: Traffic and congestion. http://wdi.worldbank.org/table/3.13\#. (2013) Accessed 11 November 2013.

Zhu, C., Zhu, Y., Lu, R., He, R., and Xia, Z. Perception and aspirations for car ownership among Chinese students attending two universities in the Yangtze Delta, China. Journal of Transport Geography 24, 315-323 (2012)

\section{Author Biographies}

Prawira Fajarindra Belgiawan is a $\mathrm{PhD}$ student in the Department of Urban Management at Kyoto University. This paper is part of his doctoral research which investigates the role of psychological factors such as attitudes and social norms on car ownership intentions.

Jan-Dirk Schmöcker is an Associate Professor in the Department of Urban Management, Kyoto University, Japan. His research interests cover travel behavioural issues as well as network modelling with a focus on public transport. Partly related to the present paper he also published in this journal recently a paper titled "Dynamic Process Model of Mass Effects" (Vol. 41(2)).

Maya Abou-Zeid is an Assistant Professor of Civil and Environmental Engineering at the American University of Beirut. Her research interests are in the areas of travel behavior modeling and forecasting, driving behavior and road safety, market research, and urban transportation planning.

Joan Walker is an Associate Professor at UC Berkeley in the Department of Civil and Environmental Engineering and Berkeley's new Center for Global Metropolitan Studies. Her research focus is behavioural modeling, emphasizing methods and their application to urban issues including health, congestion, air quality, equity, and quality of life.

Tzu-Chang Lee is an Assistant Professor at the Department of Urban Planning, National Cheng Kung University, Taiwan, where he also received his BSc and MSc degrees. He obtained his PhD at Imperial College London. His research interests are mainly related to traffic modelling and simulation, land use and transportation interaction, and transportation mode choice in urban areas.

Dick F. Ettema is an Associate Professor in the Department of Human Geography and Planning of Utrecht University in the Netherlands. His research interests include travel decision making and 
behavior change, well-being implications of travel and activity patterns and the influence of the built and social environment on physical activity and active travel.

Satoshi Fujii is a Professor of transportation and behavior science in the Department of Urban Management at Kyoto University and a special adviser for public policy to the cabinet of Japan. He has been engaged in applied psychological research for behavioral modification of travel behavior. 